Article

\title{
Brosimum Alicastrum as a Novel Starch Source for Bioethanol Production
}

\author{
Edgar Olguin-Maciel ${ }^{1}$, Alfonso Larqué-Saavedra ${ }^{2}$, Daisy Pérez-Brito ${ }^{3}$, Luis F. Barahona-Pérez ${ }^{1}$, \\ Liliana Alzate-Gaviria ${ }^{1}$, Tanit Toledano-Thompson ${ }^{1}$, Patricia E. Lappe-Oliveras ${ }^{4}$, \\ Emy G. Huchin-Poot ${ }^{1}$ and Raúl Tapia-Tussell ${ }^{1, *}$ \\ 1 Unidad de Energía Renovable, Centro de Investigación Científica de Yucatán AC, \\ Carretera Sierra Papacal-Chuburná Puerto, Km 5, Sierra Papacal, Mérida 97302, Yucatán, Mexico; \\ edgar.olguin@cicy.mx (E.O.-M); barahona@cicy.mx (L.F.B.-P); lag@cic.mx (L.A.-G); tanit@cicy.mx (T.T.-T); \\ eghp.09@gmail.com (E.G.H.-P) \\ 2 Unidad de Recursos Naturales, Centro de Investigación Científica de Yucatán AC, \\ Calle 43 No. 130 x 32 y 34 Col. Chuburná de Hidalgo, Mérida 97205, Yucatán, Mexico; larque@cicy.mx \\ 3 Laboratorio GeMBio, Centro de Investigación Científica de Yucatán AC, \\ Calle No. 13043 x 32 y 34 Col. Chuburná de Hidalgo, Mérida 97205, Yucatán, Mexico; daisypb@cicy.mx \\ 4 Laboratorio de Micología, Instituto de Biología, Universidad Nacional Autónoma de México, \\ Ciudad de México 04510, Mexico; lappe@ib.unam.mx \\ * Correspondence: rtapia@cicy.mx; Tel.: +52-999-942-8330
}

Received: 4 September 2017; Accepted: 6 October 2017; Published: 12 October 2017

\begin{abstract}
Ramon (Brosimum alicastrum) is a forest tree native to the Mesoamerican region and the Caribbean. The flour obtained from Ramon seeds is $75 \%$ carbohydrate, of which $63 \%$ is starch, indicating its potential as a novel raw material for bioethanol production. The objective of this study was to produce ethanol from Ramon flour using a $90{ }^{\circ} \mathrm{C}$ thermic treatment for $30 \mathrm{~min}$ and a native yeast strain (Candida tropicalis) for the fermentation process. In addition, the structure of the flour and the effects of pretreatment were observed via scanning electron microscopy. The native yeast strain was superior to the commercial strain, fermenting $98.8 \%$ of the reducing sugar (RS) at $48 \mathrm{~h}$ and generating $31 \%$ more ethanol than commercial yeast. One ton of flour yielded $213 \mathrm{~L}$ of ethanol. These results suggest that Ramon flour is an excellent candidate for ethanol production. This is the first report on bioethanol production using the starch from Ramon seed flour and a native yeast strain isolated from this feedstock. This alternative material for bioethanol production minimizes the competition between food and energy production, a priority for Mexico that has led to significant changes in public policies to enhance the development of renewable energies.
\end{abstract}

Keywords: bioethanol production; starch; Brosimum alicastrum; Candida tropicalis

\section{Introduction}

The continued depletion of fossil fuels and the need to reduce greenhouse gas emissions to mitigate global warming have generated an increasing worldwide interest in alternative energy sources $[1,2]$. For this reason, the biofuel market has shown exponential growth in global production in the past decade [3]. Among biofuels, bioethanol is the most frequently used, with a 2016 worldwide production of 26,584 million gallons [4]. USA and Brazil are the major producers, generating $87 \%$ of global bioethanol [3].

To avoid conflicts arising from designating land for food or energy production, the search and characterization of inedible energy crops with a low requirement of agricultural management is important [5]. The availability of local raw materials is also an important issue that must be addressed when assessing feedstock viability [6]. In this regard, one alternative starch source is the Ramon tree 
seed (Brosimum alicastrum Sw.) This tree is native to the Mesoamerican region and the Caribbean, inhabiting warm, semi-warm, tropical, and mild climates—from 10 to $1600 \mathrm{~m}$ above sea level—and growing in the wild in association with a variety of vegetation [7].

The north of the Yucatán peninsula consists mainly of semi-arid lands with poor soil quality that does not support cultivation. B. alicastrum is one of the few forest species that actually thrive in this area, with a seed production of $95.5 \mathrm{~kg}$ per tree per year, representing an annual seed productivity of 28.6 tons in a commercial plantation of 300 trees per hectare or 19.1 tons with 200 trees per hectare [7]. The flour obtained from Ramon seeds is $75 \%$ carbohydrate, of which, $63 \%$ is starch, indicating its potential as a raw material for the bioethanol production, given that, nowadays, this seed is rarely used for human consumption among the population of the Yucatan Peninsula [8].

Since this source of starch has not been studied previously for bioethanol production, it is important to isolate native strains from the biomass that naturally ferment the tree fruits, allowing better adaptation to the fermentation process, thus reducing time and production costs of second-generation ethanol, and increasing yield $[9,10]$. In a previous study about Ramon's mycobiota, different species of native yeasts were isolated and characterized; the species Candida tropicalis was able to produce ethanol from starch [11]. Therefore, this Candida species strain could be a good candidate for the fermentation of Ramon's must in the place of commercial strains as Saccharomyces cerevisiae.

The aim of this work was to use this novel source of starch and test a native yeast strain in combination with a thermic pretreatment for bioethanol production.

\section{Materials and Methods}

\subsection{Raw Material}

B. alicastrum seeds were collected from different locations in the State of Yucatan, Mexico. Each seed coat was removed manually. Then, the seeds were dried in a convection oven (Binder, Fed model $115^{\circledR}$, Tuttlingen, Germany) at $70{ }^{\circ} \mathrm{C}$ for $72 \mathrm{~h}$, after which they were stored in a desiccator until milling. The flour was obtained according to methodology described by Perez-Pacheco [8]. The starch content was determined as per the method described previously by Holm [12] and protein content was determined in accordance with Association of Analytical Chemists (AOAC) methods for proteins (920.87) [13].

\subsection{Scanning Electron Microscopy (SEM)}

To study the microscopic structure of the flour and the effect of pretreatment, a scanning electron microscope (SEM, model JSM-6360LV, JEOL, Tokyo, Japan) was used. Flour samples were mounted on a metallic stub using double-sided adhesive tape coated with a $15 \mathrm{~nm}$ gold layer and observed at $20 \mathrm{kV}$.

\subsection{Analytical Methods}

Reducing sugar (RS) concentrations were determined in the hydrolysates and during fermentation by the 3,5-dinitrosalicylic acid method [14]. The sample absorbance was measured at $550 \mathrm{~nm}$. For ethanol quantification, $25 \mathrm{~mL}$ of fermented sample was diluted with $25 \mathrm{~mL}$ of distilled water and distilled at $100{ }^{\circ} \mathrm{C}$ until $25 \mathrm{~mL}$ of distillate was recovered. Gas chromatograph (GC) analysis was carried out in a PerkinElmer Clarus 500 gas chromatograph (PerkinElmer, Waltham, MA, USA) equipped with a Flame Ionization Detector. An EC-WAX capillary column $(30 \mathrm{~m} \times 0.32 \mathrm{~mm}$ ID (Internal diameter) $\times 0.25 \mu \mathrm{m}$ film thickness, Alltech) was used. The carrier gas was $\mathrm{N}_{2}$ at $7 \mathrm{psi}$ and $80 \mathrm{~mL} \mathrm{~min}{ }^{-1}$. Temperature conditions were $50^{\circ} \mathrm{C}$ for $1 \mathrm{~min}$, a $35^{\circ} \mathrm{C} \mathrm{min}^{-1}$ ramp to $70{ }^{\circ} \mathrm{C}$ for $10 \mathrm{~min}$., and a $35^{\circ} \mathrm{C} \mathrm{min}^{-1}$ ramp to $100^{\circ} \mathrm{C}$ for $7 \mathrm{~min}$. Injector temperature was $150{ }^{\circ} \mathrm{C}$ and the FID detector temperature was $200{ }^{\circ} \mathrm{C}$. The sample injection volume was $1 \mu \mathrm{L}$. The external standard technique was used for quantification of ethanol. The results were considered statistically significant if $p<0.05$ using 
Tukey's test. All of the statistical analyses were performed using SPSS $16{ }^{\circledR}$ (SPSS Inc., IBM, Armonk, NY, USA). All experiments were conducted in triplicate.

\subsection{Enzymatic Hydrolysis}

A suspension of Ramon flour $(100 \mathrm{~mL}, 20 \% w / v)$ in sodium phosphate buffer $(0.1 \mathrm{M})$ was prepared and heated to $90 \pm 2{ }^{\circ} \mathrm{C}$ for $30 \mathrm{~min}$ in a water bath recirculator (Polyscience ${ }^{\circledR}$, model 9505, Niles, IL, USA) with constant agitation at $20 \mathrm{rpm}$. The samples were cooled to room temperature and used straightaway in a liquefaction process.

\subsubsection{Liquefaction}

The $\mathrm{pH}$ of the flour suspension was adjusted to 6 with an alkaline solution of $\mathrm{KOH}(1 \mathrm{~N})$. Then, $60 \mathrm{ppm}$ of $\mathrm{Ca}^{2+}$ was added in the form of calcium chloride in addition to $0.075 \mathrm{U}$ of $\alpha$-amylase enzyme (a-7595 Sigma-Aldrich ${ }^{\circledR}$, St Luis, MO, USA) per gram of starch present in the flour in accordance with Barquera [15]. The mixture was homogenized, placed in the water bath recirculator and incubated at $85 \pm 2{ }^{\circ} \mathrm{C}$ for $1 \mathrm{~h}$ with constant agitation at $25 \mathrm{rpm}$.

\subsubsection{Saccharification}

The suspension obtained from the liquefaction was adjusted to $\mathrm{pH} 4.5$ with Hydrochloric acid $(\mathrm{HCl})(1 \mathrm{~N})$. Then, $0.36 \mathrm{U}$ amyloglucosidase enzyme (A-7095, Sigma-Aldrich ${ }^{\circledR}$ ) was added per gram of starch present in the flour and incubated at $60 \pm 2{ }^{\circ} \mathrm{C}$ for $24 \mathrm{~h}$ with constant orbital agitation at $100 \mathrm{rpm}$ on a MAXQ ${ }^{\mathrm{TM}} 4000$ Benchtop Orbital Shaker (Thermo Scientific, Norcross, GA, USA). After saccharification, samples were taken to measure the reducing sugar levels [15].

\subsection{Yeast Strains}

Candida tropicalis (PL1) was isolated from the pericarp of the B. alicastrum fruit. It was characterized by phenotypic and molecular tests [14]. Commercial Saccharomyces cerevisiae was obtained from Safmex S.A. de C.V. (Toluca, México). Both yeasts were maintained in tubes with YPD (yeast extract; peptone and dextrose) medium containing yeast extract $\left(5 \mathrm{~g} \cdot \mathrm{L}^{-1}\right)$ peptone $\left(10 \mathrm{~g} \cdot \mathrm{L}^{-1}\right)$ and dextrose $\left(20 \mathrm{~g} \cdot \mathrm{L}^{-1}\right)$. The inoculum of both strains was prepared in YPD supplemented with ammonium sulfate $\left(1.5 \mathrm{~g} \cdot \mathrm{L}^{-1}\right)$ as a nitrogen source and incubated with orbital agitation at $30 \pm 2{ }^{\circ} \mathrm{C}$ for $6 \mathrm{~h}$. In all cases, the inoculum used had a concentration of $3 \times 10^{7}$ cell $\mathrm{mL}^{-1}$.

\subsection{Fermentation Conditions}

Fermentation was performed in cotton stoppered 150 mL-Erlenmeyer flasks, under limited anaerobic conditions, with $40 \mathrm{~mL}$ of hydrolyzed flour, and $10 \mathrm{~mL}$ of water at an initial concentration of $77.18 \mathrm{~g} \cdot \mathrm{L}^{-1}$ of RS. The $\mathrm{pH}$ was adjusted to 4.5 , and $1.2 \mathrm{~mL}$ ammonium sulfate $(1 \mathrm{~N})$ was added. Two $\mathrm{mL}(4 \% v / v)$ of inoculum were added to each sample and incubated at $35 \pm 3{ }^{\circ} \mathrm{C}$ for $48 \mathrm{~h}$ in a drying chamber (Binder, Fed model $115^{\circledR}$, Tuttlingen, Germany) without agitation. The fermentation product was centrifuged at $4000 \mathrm{rpm}$ for $20 \mathrm{~min}$, and the supernatant was collected for distillation, $25 \mathrm{~mL}$ of fermented sample was diluted with $25 \mathrm{~mL}$ of distilled water, and distilled at $100{ }^{\circ} \mathrm{C}$, until $25 \mathrm{~mL}$ of distillate was recovered. All of the tests were repeated three times.

\section{Results and Discussion}

Flour obtained from Ramon seeds exhibited a particle size between 0.425 and $0.600 \mathrm{~mm}$ in diameter and $12 \%$ in moisture. This flour contains a high proportion of starch $(61 \%)$ and $12.24 \%$ total protein. The starch content is similar to the main sources of starch used for biofuels, including cereals (60-80\% starch), legumes (25-50\% starch), tubers and roots (60-90\% starch), and green and immature fruits (as much as $70 \%$ starch) $[16,17]$. The main crops used are sorghum, wheat, cassava, potatoes, and sweet potatoes $[16,18,19]$, in addition to maize, which is the most widely-used starch 
crop for bioethanol production and has a starch content ranging from 60 to $85 \%$ depending on the variety [20-22].

Scanning electron microscopy images showed a large amount of starch granules embedded in a protein matrix (Figure 1a), which might act as a barrier during the amylolysis of starch granules [23,24]. Martin and Lopez [25] suggest that these granules provide resistance to enzymatic activity, as they are tightly packed by intra- and intermolecular hydrogen bonds in a polycrystalline state, making them resistant to enzymatic treatments. Figure 1a shows different (spherical, elliptic, and truncated) starch granule shapes, which agree with those reported for starch granules from different sources such as potato, cassava, and chestnut [26,27]. In Figure 1b, the spherical shape of a starch granule with dimensions of $15 \times 15 \mu \mathrm{m}$ is depicted, which agrees with the shape reported by Pérez-Pacheco et al. [8], the first to study Ramon flour starch. They observed that Ramon starch granules have an oval to spherical shape with diameters ranging from 6 to $15 \mu \mathrm{m}$.
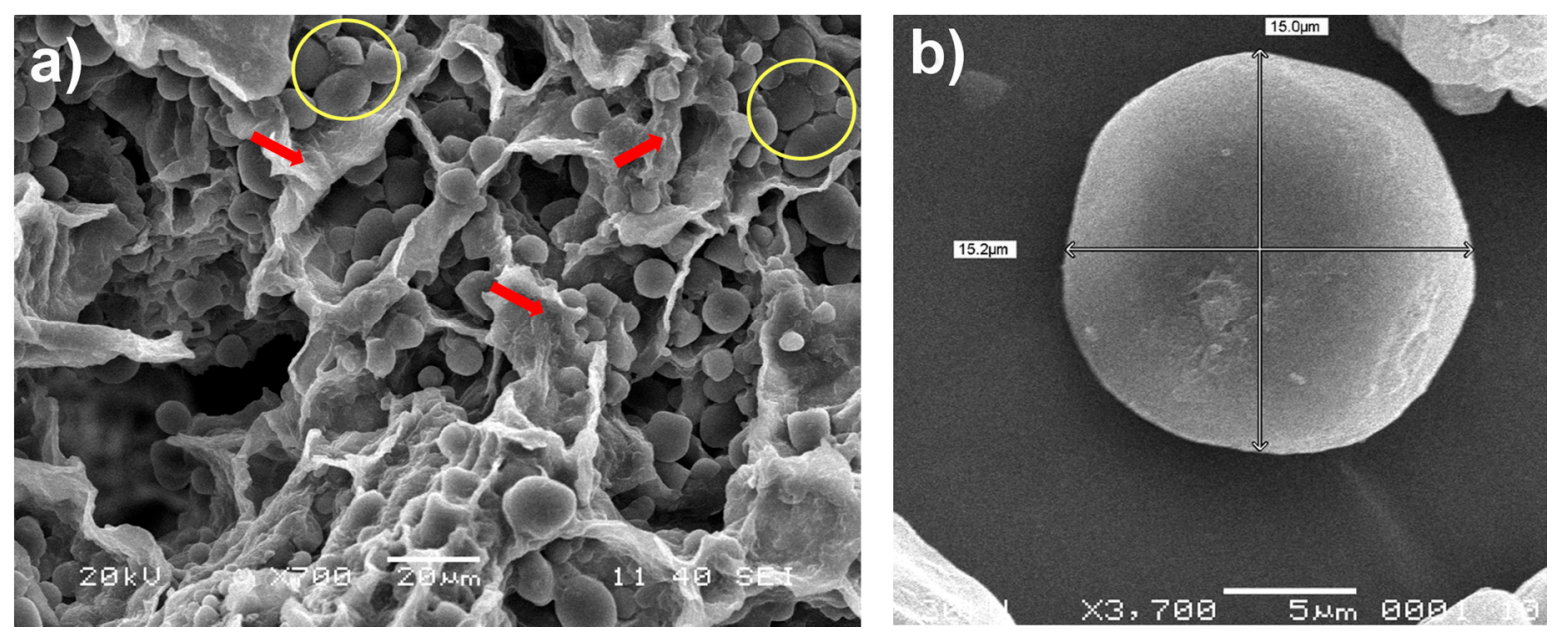

Figure 1. Scanning electron microscopy (SEM) of B. alicastrum flour: (a) starch granules embedded in a flour protein matrix; and (b) the size and shape of starch granules.

\subsection{Enzymatic Hydrolysis}

The effects of heating the flour suspension are shown in Figure $2 b$, in which a modification of the protein matrix enhanced starch granule release compared to that in the untreated flour (Figure 2a), in which granules were trapped and clustered in the protein matrix. The majority of released granules maintained their structure, even though we used higher temperatures than those used by Chen et al. [28], who reported that hydrothermal treatment at $62{ }^{\circ} \mathrm{C}$ induces changes to the physicochemical properties of corn starch without destroying granule structure. The observed physicochemical changes involved the release of dextrins and glucose molecules in small amounts into the solution [29], which coincides with the present study, in which the RS value increased from $1.4 \mathrm{~g} \cdot \mathrm{L}^{-1}$ to $5.9 \mathrm{~g} \cdot \mathrm{L}^{-1}$ after the Ramon flour suspension was heated.

Figure $2 \mathrm{~b}$ shows that complete gelatinization was not obtained. This can be attributed to this flour being not only starch, but a mixture that includes other components, such as proteins, which could interfere negatively in the process of gelatinization. Furthermore, it might indicate that the temperature of Ramon starch gelatinization is higher than $80^{\circ} \mathrm{C}$, the temperature at which the majority of starches gelatinize [30]. This agrees with Perez Pacheco et al. [8], who found that the gelatinization point for starch granules extracted from Ramon flour is $83.05^{\circ} \mathrm{C}$. Heat treatment followed by hydrolysis increased the RS value by $33 \%$ compared with that in untreated flour (Figure 3 ). 

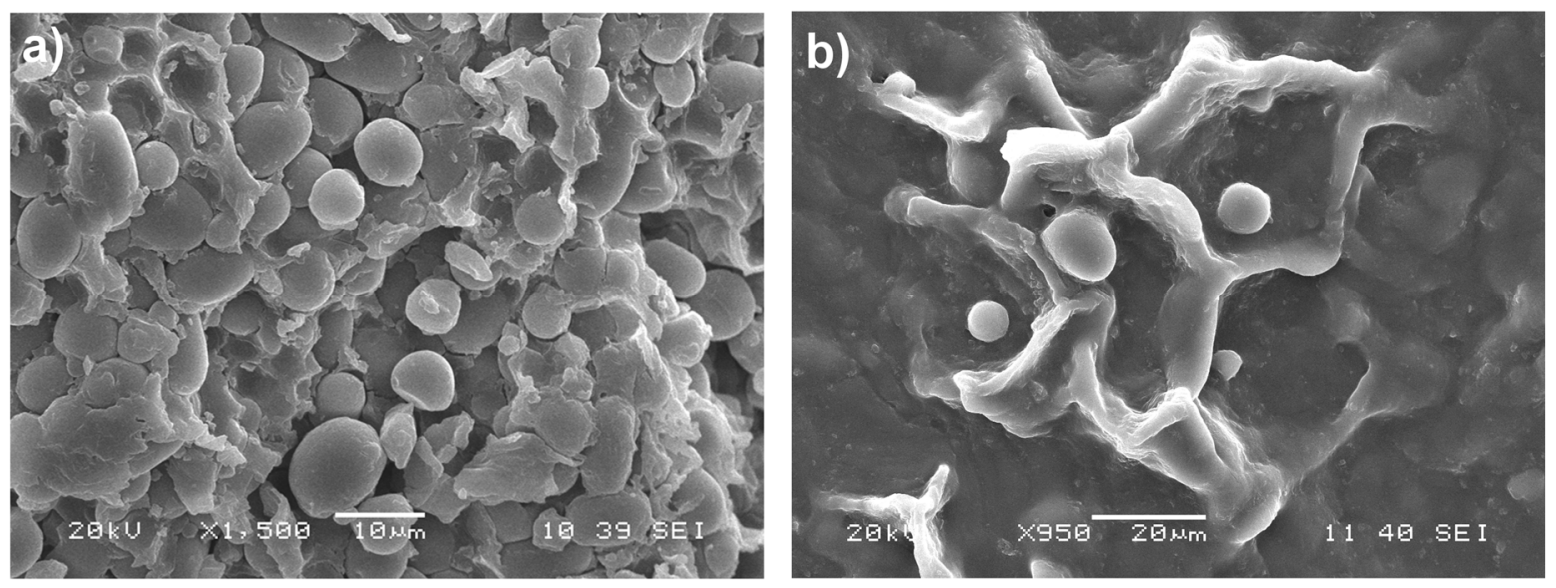

Figure 2. Scanning electron microscopy (SEM) of B. alicastrum flour: (a) without pretreatment; and (b) after thermic pretreatment $90^{\circ} \mathrm{C}$ for $30 \mathrm{~min}$.

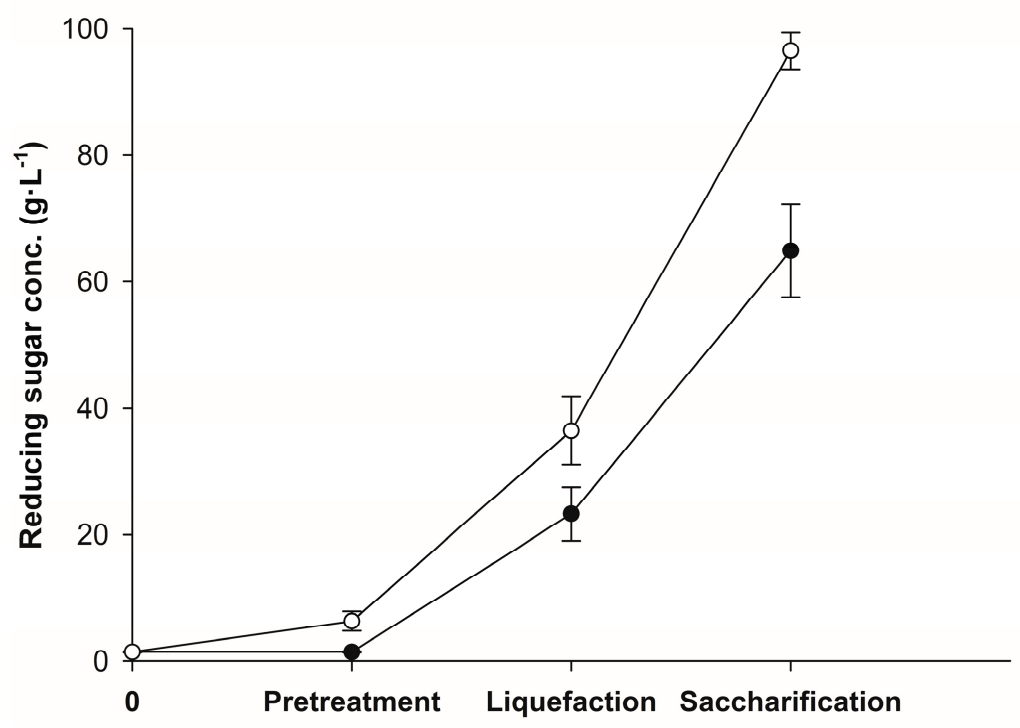

Figure 3. Production dynamics of reducing sugars in the Ramon flour enzymatic hydrolysis. Open symbols thermic pretreatment $90{ }^{\circ} \mathrm{C}$ for $30 \mathrm{~min}$. and solid symbols without pretreatment. The results are represented as the mean \pm standard deviation of three parallel measurements $(n=3)$.

RS concentrations obtained at the two steps (liquefaction and saccharificaction) of the enzymatic hydrolysis were higher in the thermal pretreatment (36.5 and $96.2 \mathrm{~g} \cdot \mathrm{L}^{-1}$, respectively). These values are similar to those obtained by Baks et al. [31], who reported a range of $15-30 \mathrm{~g} \cdot \mathrm{L}^{-1}$ after liquefaction and $40-98 \mathrm{~g} \cdot \mathrm{L}^{-1}$ after saccharification. These results showed that a combination of thermal pretreatment ( $90{ }^{\circ} \mathrm{C}$ for $30 \mathrm{~min}$ ) with the enzyme concentrations used in this study providing adequate RS concentrations for the fermentation process.

Heating exposes more starch granules to the action of the enzymes, as described by Dhital et al. [24], Martín and López [25], and Pepe et al. [32], who suggest that heating the starch in an aqueous suspension increases susceptibility to enzymatic hydrolysis. When the starch suspension is heated, water first enters the amorphous regions, specifically in the hilum, which expands and transmits a disruptive force to the crystalline regions. These changes are accompanied by the swelling of granules which, under agitated conditions, increase viscosity, leading to eventual collapse and the formation of a paste. When this occurs, $\alpha$-amylase molecules progressively digest starch granules as they gelatinize [33]. In contrast, in unmodified starches, enzymatic activity is decreased by several 
factors, including the amylose-amylopectin ratio and interaction with protein components and lipids. Among others, Wang et al. [34] established that unmodified starch is slowly digested by enzymes due to the high molecular order of the intact granules; processes such as cooking disrupt the ordered structure, resulting in increased susceptibility to enzymatic digestion.

\subsection{Fermentation}

After the production of hydrolysates from pretreated flour, the maximum RS level obtained had a concentration of $77.18 \mathrm{~g} \cdot \mathrm{L}^{-1}$. It was fermented using two strains of yeast: an industrial strain of S. cerevisiae $\left(\right.$ Safoeno ${ }^{\circledR}$ ) and a strain of $C$. tropicalis (PL1) isolated from Ramon seeds. Both strains generated different fermentation profiles (Figure 4).
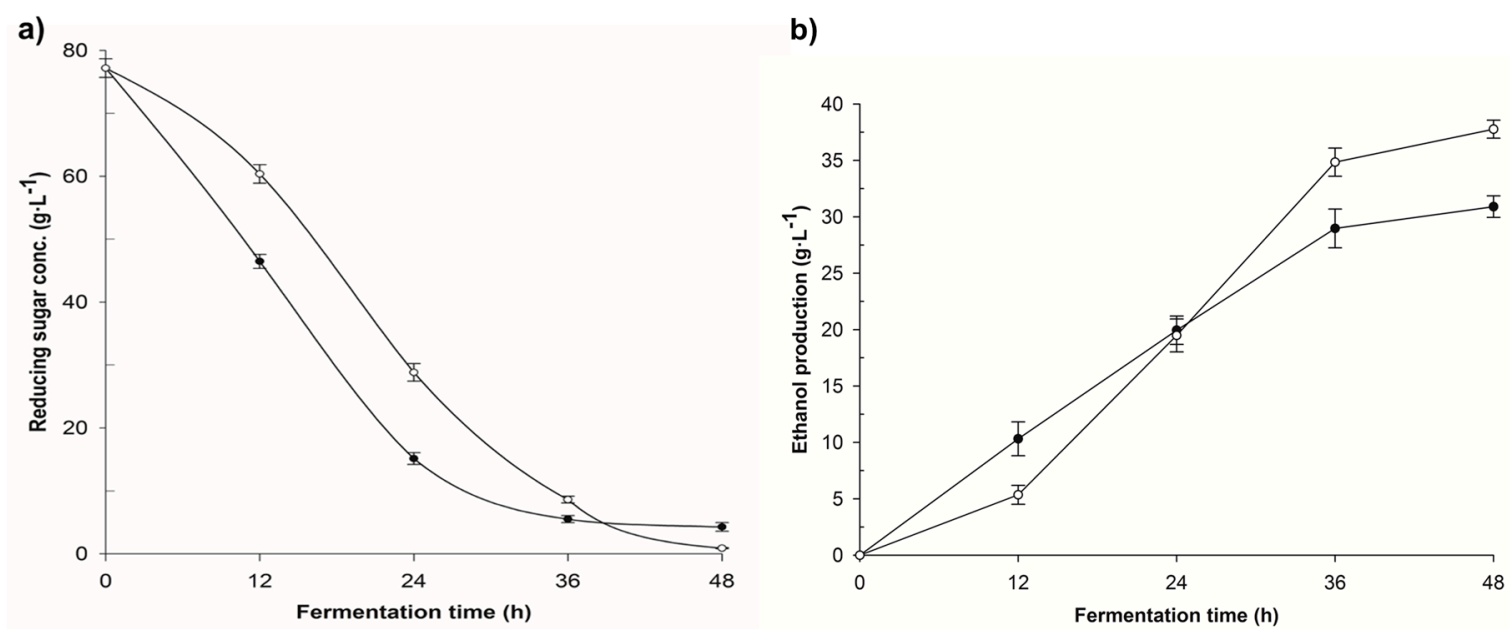

Figure 4. Fermentation profile of flour from B. alicastrum using two yeast strains: Solid symbols (S. cerevisiae, Safoeno ${ }^{\circledR}$ ) and open symbols (C. tropicalis, PL1). (a) Represents the consumption of reducing sugars and $(\mathbf{b})$ shows ethanol production. The results are represented as the mean \pm standard deviation of three parallel measurements $(n=3)$.

The Safoeno ${ }^{\circledR}$ strain began rapidly consuming RS, fermenting $80.4 \%$ of the total initial sugars in the first $24 \mathrm{~h}$ (Figure 4a). After $36 \mathrm{~h}$, the fermentation process was stopped, because the yeast did not continue fermenting, leaving a residual $5 \%$ of RS. For the PL1 strain, the first $12 \mathrm{~h}$ of fermentation was slower, and at $24 \mathrm{~h}$, only $60 \%$ of the RS had been consumed. However, this strain fermented $98.8 \%$ of RS after $48 \mathrm{~h}$. Figure $4 \mathrm{~b}$ shows the marked difference between the ethanol production profiles of both strains. In the first $12 \mathrm{~h}$, the $S$. cerevisiae was more efficient than $C$. tropicalis, whereas between 24 and $48 \mathrm{~h}$ the native strain (C. tropicalis) produced more ethanol $\left(37.76 \mathrm{~g} \cdot \mathrm{L}^{-1}\right)$ than the commercial strain $\left(30.9 \mathrm{~g} \cdot \mathrm{L}^{-1}\right)$. This is associated with the ability of $C$. tropicalis to produce ethanol from starch through the production of glucoamylase [35,36], which allows dextrin degradation during the hydrolysis process, leading to a more efficient fermentation. GC analysis showed one dominant analyte peak, which was identified as ethanol (Figure 5) based on the results obtained using standard solutions.

As shown in Figure $5 b$, the commercial S. cerevisiae $\left(\right.$ Safoeno ${ }^{\circledR}$ ) strain produced less ethanol than the native yeast strain isolated from B. alicastrum PL1 (Figure 5c). Currently, there is a tendency to use strains isolated from spontaneous fermentations, because it is assumed that they will be better adapted to the system. The calculation of ethanol production for both strains is shown in Figure 6 . Strain PL1 (Candida tropicalis) exhibited a 31\% increase in ethanol production with respect to strain Safoeno ${ }^{\circledR}$ (S. cerevisiae) with values of 213 and $147 \mathrm{~mL} \cdot \mathrm{kg}^{-1}$ flour, respectively. 

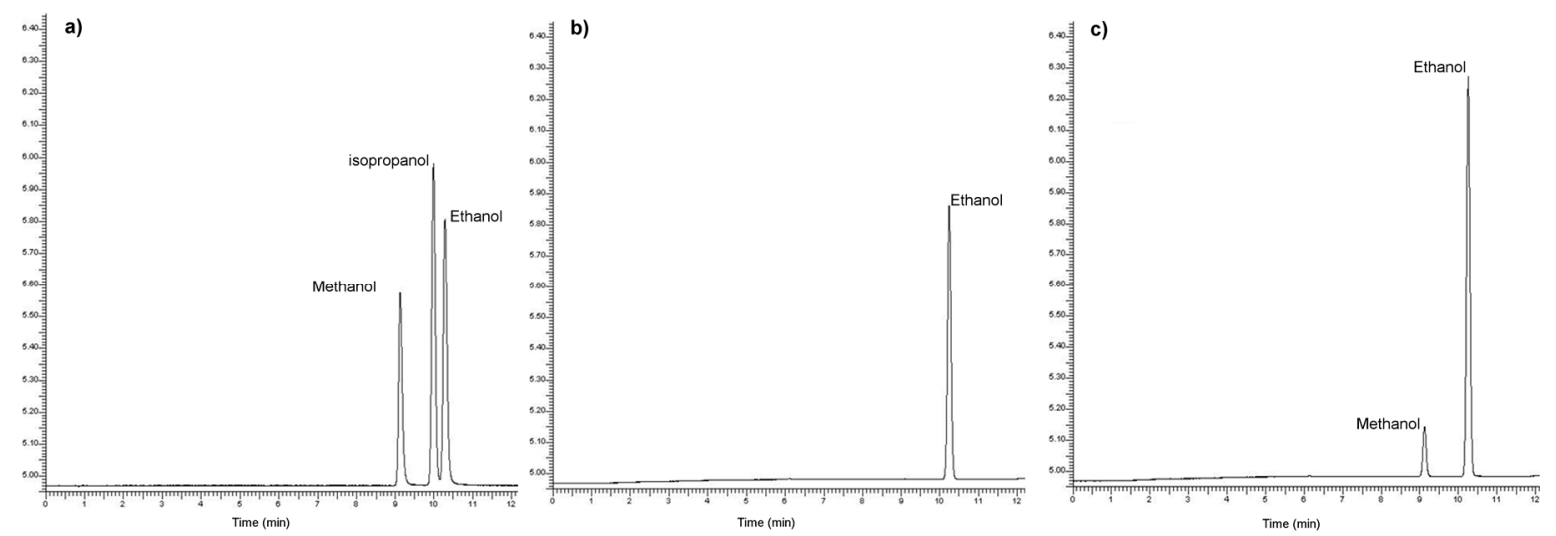

Figure 5. GC chromatogram of the B. alicastrum distillation product fermented with two yeast strains: (a) Internal standard; (b) S. cerevisiae (Safoeno ${ }^{\circledR}$ ); and (c) C. tropicalis (PL1).

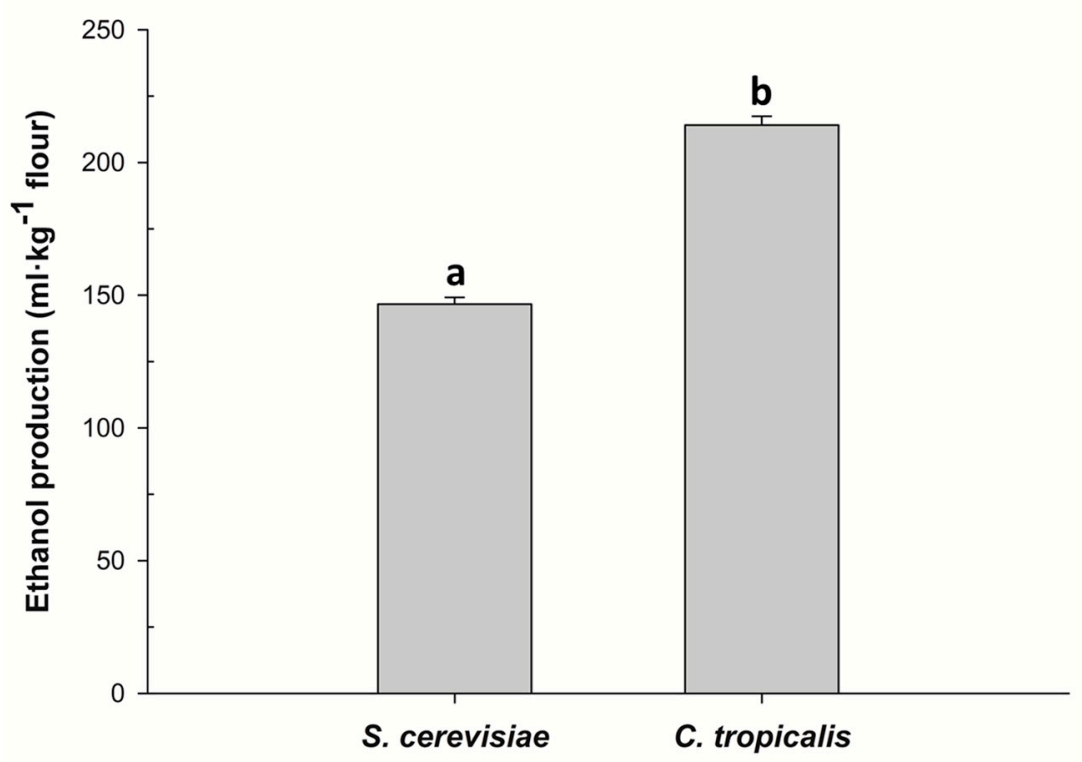

Figure 6. Comparison of ethanol yields obtained after fermentation of B. alicastrum flour with two yeast strains. The results are represented as the mean \pm standard deviation of three parallel measurements $(n=3)$. Different letters represent significant differences at $p<0.05$.

With the yield obtained in this work, it is possible to produce $213 \mathrm{~L}$ of ethanol per ton of flour. Taking into account that B. alicastrum produces $95.5 \mathrm{~kg}$ of seed per tree per year [7], in a commercial plantation of 300 trees per ha, 11.5 tons of flour could be produced. This would represent the production of $2500 \mathrm{~L}$ of ethanol per ha per year, which is $50 \%$ of the maximum theoretical yield of this raw material, making it attractive as an alternative source for bioethanol production.

When comparing these yields with those obtained from maize $\left(417 \mathrm{~L} \cdot\right.$ ton $^{-1}, 3336 \mathrm{~L}$ ethanol per ha [37]), which is the main source of ethanol production from starch, we see that the yield from Ramon is $25 \%$ lower than that from corn. However, one of the main advantages of Ramon starch is that, unlike corn, it does not compete with the basic diet of the Mexican population. Moreover, as Ramon is a perennial species, it contributes to carbon capture and helps to reduce the negative effects of climate change. Neither does this tree require agricultural inputs for its establishment nor management, which dampens biofuel production costs. In addition, as a dense, slow-growing timber tree, it is likely to be used in carbon dioxide capture programs (or bonds) by producers. This study demonstrates the potential of Ramon tree seeds for use in the sustainable production of bioethanol, which is a priority 
for Mexico, which has led to significant changes in public policies to enhance the development of renewable energies.

\section{Conclusions}

Ramon flour contains a high concentration of starch that can be converted into fermentable sugars. Ramon seeds are rarely used for human consumption, and their use as animal feed is negligible. The strain PL1 (C. tropicalis) isolated from Ramon fruits was superior to the Safoeno ${ }^{\circledR}$ strain, fermenting $98.8 \%$ of RS after $48 \mathrm{~h}$ and yielding $31 \%$ more ethanol than commercial yeast. We calculated $213 \mathrm{~L}$ of ethanol per ton of flour, suggesting that Ramon flour is an excellent candidate for ethanol production when used in combination with a thermic treatment $\left(90{ }^{\circ} \mathrm{C}\right.$ for $\left.30 \mathrm{~min}\right)$ and a native yeast strain. This is the first report of bioethanol production from Ramon starch using native yeast strains isolated from this feedstock.

Acknowledgments: This work was financially supported by the Consejo Nacional de Ciencia y Tecnología (CONACYT) of Mexico.

Author Contributions: All the authors contributed to this work. Raul Tapia-Tussell, Alfonso Larque-Saavedra, and Daisy Perez-Brito conceived, designed, and wrote the paper; Edgar Olguin-Maciel, Emy G. Huchin-Poot, and Tanit Toledano-Thompson performed the experiments and analyzed the data; and Luis F. Barahona-Perez, Liliana Alzate-Gaviria, and Patricia Lappe Oliveras participated in the data analysis and writing of the paper.

Conflicts of Interest: The authors declare no conflict of interest.

\section{References}

1. Pervez, S.; Aman, A.; Iqbal, S.; Siddiqui, N.N.; Qader, S.A.U. Saccharification and liquefaction of cassava starch: An alternative source for the production of bioethanol using amylolytic enzymes by double fermentation process. BMC Biotechnol. 2014, 14, 49. [CrossRef] [PubMed]

2. Bhadana, B.; Chauhan, M. Bioethanol production using Saccharomyces cerevisiae with different perspectives: Substrates, growth variables, inhibitor reduction and immobilization. Ferment. Technol. 2016, 5, 131. [CrossRef]

3. Lamers, P.; Hamelinck, C.; Junginger, M.; Faaij, A. International bioenergy trade. A review of past developments in the liquid biofuel market. Renew. Sustain. Energy Rev. 2011, 15, 2655-2676. [CrossRef]

4. Renewable Fuels Association. Available online: http://www.ethanolrfa.org/resources/industry/statistics (accessed on 7 July 2017).

5. Moshi, A.P.; Crespo, C.F.; Badshah, M.; Hosea, K.M.M.; Mshandete, A.M.; Elisante, E.; Mattiasson, B. Characterization and evaluation of a novel feedstock, Manihot glaziovii, Muell. Arg, for production of bioenergy carriers: Bioethanol and biogas. Bioresour. Technol. 2014, 172, 58-67. [CrossRef] [PubMed]

6. Villegas-Silva, P.A.; Toledano-Thompson, T.; Canto-Canché, B.B.; Larqué-Saavedra, A.; Barahona-Pérez, L.F. Hydrolysis of Agave fourcroydes Lemaire (henequen) leaf juice and fermentation with Kluyveromyces marxianus for ethanol production. BMC Biotechnol. 2014, 14, 14. [CrossRef] [PubMed]

7. Hernández-González, O.; Vergara-Yoisura, S.; Larqué-Saavedra, A. Studies on the productivity of Brosimum alicastrum a tropical tree used for animal feed in the Yucatan Peninsula. Bothalia 2014, 44, 70-81.

8. Pérez-Pacheco, E.; Moo-Huchin, V.M.; Estrada-León, R.J.; Ortiz-Fernández, A.; May-Hernández, L.H.; Ríos-Soberanis, C.R.; Betancur-Ancona, D. Isolation and characterization of starch obtained from Brosimum alicastrum Swarts Seeds. Carbohydr. Polym. 2014, 101, 920-927. [CrossRef] [PubMed]

9. Da Silva, P.D.; Sanchez, F.C.; Ribeiro, D.M.; Freitas, A.S.; da Cruz, P.J. Use of a new Trichoderma harzianum strain isolated from the Amazon rainforest with pretreated sugar cane bagasse for on-site cellulase production. Bioresour. Technol. 2012, 107, 517-521.

10. Orencio-Trejo, M.; Torres-Granados, J.; Rangel-Lara, A.; Beltrán-Guerrero, E.; García-Aguilar, S.; Moss-Acosta, C.; Valenzuela-Soto, H.; De la Torre-Zavala, S.; Gastelum-Arellanez, A.; Martinez, A.; et al. Cellulase and Xylanase Production by the Mexican Strain Talaromyces stollii LV186 and Its Application in the Saccharification of Pretreated Corn and Sorghum Stover. Bioenergy Res. 2016, 9, 1034-1045. 
11. Huchin-Poot, E.G. Aislamiento de la microbiota del fruto de ramon Brosimum alicastrum Swartz para su uso en la producción de bioetanol. Master's Thesis, Centro de Investigación Científica de Yucatán A.C., Mérida, Mexico, 2015.

12. Holm, J.; Björck, I.; Drews, A.; Asp, N.G. A rapid method for the analysis of starch. Starch Stärke 1986, 38, 224-226. [CrossRef]

13. AOAC. Official Methods of Analysis, 15th ed.; Association of Analytical Chemists: Washington, DC, USA, 1997.

14. Miller, G.L. Use of Dinitrisalicylic acid reagent for determination of reducing sugar. Anal. Chem. 1859, 31, 426-428. [CrossRef]

15. Barquera, B.Z. Obtención de bioethanol a partir de la semilla del ramón (Brosimum alicastrum Sw.). Master's Thesis, Centro de Investigación Científica de Yucatán A.C., Mérida, Mexico, 2013.

16. Zabed, H.; Sahu, J.N.; Suely, A.; Boyce, A.N.; Faruq, G. Bioethanol production from renewable sources: Current perspectives and technological progress. Renew. Sustain. Energy Rev. 2017, 71, 475-501. [CrossRef]

17. Santana, A.L.; Meireless, M.A.A. New starches are the trend for industry applications: A review. Food Public Health 2014, 4, 229-241. [CrossRef]

18. Balat, M. Production of bioethanol from lignocellulosic materials via the biochemical pathways: A review. Energy Convers. Manag. 2011, 52, 858-875. [CrossRef]

19. Kim, S.; Dale, B.E. Global potential bioethanol production from wasted crops and crop residues. Bioenergy 2004, 24, 361-375. [CrossRef]

20. Wang, T.; Wang, M.; Hu, S.; Xiao, Y.; Tong, H.; Pan, Q.; Xue, J.; Yan, J.; Li, J.; Yang, X. Genetic basis of maize kernel starch content revealed by high-density single nucleotide polymorphism markers in a recombinant inbred line population. BMC Plant Biol. 2015. [CrossRef] [PubMed]

21. Somavat, P.; Li, Q.; Gonzalez de Mejia, E.; Liu, W.; Singh, V. Coproduct yield comparisons of purple, blue and yellow dent corn for various milling processes. Ind. Crop. Prod. 2016, 87, 266-272. [CrossRef]

22. Khan, A.H.; Minhas, N.M.; Asad, M.J.; Iqbal, A.; Ilyas, M.; Mahmood, R.J. Estimation of protein, carbohydrate, starch and oil contents of indigenous maize (Zea mayz L.) germoplasm. Eur. Acad. Res. 2014, 2, 5230-5240.

23. Altan, A. Effects of pretreatments and moisture on microestructure and physical properties of microwave expanded hull-less barley. Food Res. Int. 2014, 56, 126-135. [CrossRef]

24. Dhital, S.; Warren, F.J.; Butterworth, P.J.; Ellis, P.R.; Gidley, M.J. Mechanism of starch digestion by amylase-estructural basis for kinetic properties. Crit. Rev. Food Sci. Nutr. 2015. [CrossRef]

25. Martín, J.C.; López, E. Modificación física del almidón de yuca y evaluación de la susceptibilidad a la hidrólisis enzimática por una alfa amilasa. Rev. Colomb. Quim. 2009, 38, 395-408.

26. Hernández-Medina, M.; Torruco-Uco, J.G.; Chel-Guerrero, L.; Betancur-Ancona, D. Caracterización fisicoquímica de almidones de tubérculos cultivados en Yucatán, México. Cienc. Tecnol. Aliment. 2008, 28, 718-726. [CrossRef]

27. Medina, J.A.; Salas, J.C. Caracterización morfológica del gránulo de almidón nativo: Apariencia, forma, tamaño y su distribución. Rev. Ing. 2008, 27, 56-62.

28. Chen, X.; He, X.; Huang, Q. Effects of hidrothermal pretreatment on subsequent octenysuccinic anhydride (OSA) modification of cornstarch. Carbohydr. Polym. 2014, 101, 493-498. [CrossRef] [PubMed]

29. Sakinah, A.M.; Ismail, A.F.; Hassan, O.; Zularisam, A.W.; Illias, R.M. Influence of starch pretreatment on yield of cyclodextrins and performance of ultrafiltration membranes. Desalination 2009, 239, 317-333. [CrossRef]

30. Copeland, L.; Blazek, J.; Salman, H.; Chiming, M.T. Form and functionality of starch. Food Hydrocoll. 2009, 23, 1527-1534. [CrossRef]

31. Baks, T.; Bruins, M.E.; Matser, A.M.; Janssen, A.E.M.; Boom, R.M. Effect of gelatinization and hydrolysis conditions on the selectivity of starch hydrolysis with amylase from Bacillus lincheniformis. J. Agric. Food Chem. 2008, 56, 488-495. [CrossRef] [PubMed]

32. Pepe, L.S.; Moraes, J.; Albano, K.M.; Telis, V.R.N.; Franco, C.M.L. Effect of heat moisture treatment on the structural, physicochemical, and rheological characteristics of arrowroot starch. Food Sci. Technol. Int. 2015. [CrossRef] [PubMed]

33. Wang, S.; Copeland, L. Molecular disassembly of starch granules during gelatinization and its effect on starch digestibility: A review. Food Funct. 2013, 4, 1564-1580. [CrossRef] [PubMed]

34. Wang, S.; Li, C.; Copeland, L.; Niu, Q.; Wang, S. Starch retrogradation: A Comprehensive Review. Comp. Rev. Food Sci. Food Saf. 2015, 14, 568-585. [CrossRef] 
35. Nakamura, L.K. Influence of the acceptor during transglucosylation by transglucosylamylase of Candida tropicalis. Can. J. Biochem. 1970, 48, 1260-1267. [CrossRef] [PubMed]

36. Jamai, L.; Ettayebi, K.; El Yamani, J.; Ettayebi, M. Production of ethanol from starch by free and immobilized Candida tropicalis in the presence of $\alpha$-amylase. Bioresour. Technol. 2007, 98, 2765-2770. [CrossRef] [PubMed]

37. Gumienna, M.; Szwengiel, A.; Lasik, M.; Szambelan, K.; Majchrzycki, D.; Adamczyk, J.; Nowak, J.; Czarnecki, Z. Effect of corn grain variety on the bioethanol production efficiency. Fuel 2016, 164, 386-392. [CrossRef]

(c) (C) 2017 by the authors. Licensee MDPI, Basel, Switzerland. This article is an open access article distributed under the terms and conditions of the Creative Commons Attribution (CC BY) license (http://creativecommons.org/licenses/by/4.0/). 